Original Research Paper

\title{
Diversifikasi Pengolahan Kacang Lokal Lombok Menjadi Pangan Fungsional Di Desa Ubung Lombok Tengah
}

\author{
Rina Kurnianingsih ${ }^{1}$, Sukiman ${ }^{1}$, Kurniasih Sukenti ${ }^{1}$, Nur Indah Julisaniah ${ }^{1}$

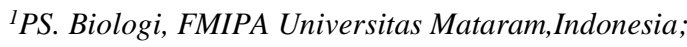

https://doi.org/10.29303/jpmpi.v3i2.1104

Sitasi: Kurnianingsih, R., Sukiman., Sukenti, K \& Julisaniah, N. I. (2021). Diversifikasi Pengolahan Kacang Lokal Lombok Menjadi Pangan Fungsional Di Desa Ubung Lombok Tengah. Jurnal Pengabdian Magister Pendidikan IPA 4(4)

\section{Article history}

Received: 02 Oktober 2021

Revised: 20 Oktober 2021

Accepted: 07 November 2021

*Corresponding Author: Rina

Kurnianingsih, PS. Biologi,

Universitas Mataram, Mataram, Indonesia;

Email:

rkurnianingsih@unram.ac.id
Abstract: Salah satu kacang lokal yang ada di NTB adalah kacang komak, meskipun hanya sebagai tanaman tumpangsari. Penanaman belum dilakukan dalam skala luas, namun untuk tumpangsari, produksi kacang komak bisa mencapai 1,5 ton per hektar. Keistimewaan dari kacang komak adalah mengandung antioksidan 10 kali lipat dari asam askorbat, bersifat hipo-kolesterol dan hipoglikemik. Kacang komak mempunyai kadar protein cukup tinggi dan komposisi asam amino yang baik sehingga berpotensi untuk mengatasi kekurangan protein. Namun saat ini, pengolahan kacang-kacangan menjadi pangan fungsional sebagai sumber protein alternatif dan produk yang bernilai ekonomi tinggi masih sangat kurang. Permasalahan lainnya yang terjadi di masyarakat (mitra) adalah masih ditemukannya status stunting dan gizi buruk. Salah satu penyebab terjadinya stunting dan gizi buruk adalah kurangnya pengetahuan masyarakat dan sosial ekonomi masyarakat. Selain itu, meningkatnya jumlah pengangguran pada kondisi pandemi saat ini juga menjadi masalah yang terjadi pada mitra. Solusi yang ditawarkan pada program pengabdian ini adalah penyuluhan tentang kandungan nilai gizi dari kacang-kacangan, pelatihan pengolahan kacang lokal Lombok menjadi pangan fungsional sebagai sumber protein alternatif dan dapat menjadi produk bernilai ekonomi tinggi, serta penyuluhan tentang pengemasan produk pangan. Tahap pelaksaaan kegiatan pengabdian dilaksanakan dalam bentuk penyuluhan dan praktek pembuatan produk pangan fungsional berbasis kacang lokal. Kegiatan dilakukan di aula Kantor Desa Ubung. Sesi penyuluhan atau penyampaian materi tentang jenis kacang lokal Lombok, kandungan nutrisi, pangan fungsiona, dan pengemasan produk dan sesi praktek membuat produk pangan fungsional yaitu tempe komak, nugget tempe komak dan sari kacang merah. Antusiasme peserta pada kegiatan praktek sangat tinggi, ini dilihat dari keaktifan peserta dan pertanyaan yang diajukan kepada tim pengabdian. Beberapa pertanyaan yang diajukan oleh peserta diantaranya terkait dengan masa simpan tempe komak, kualitas tempe komak (aroma, rasa) dan peluang usaha untuk mengembangkan tempe komak. Berdasarkan hasil evaluasi, terjadi peningkatan pengetahuan dan pemahaman peserta tentang pengolahan kacang lokal menjadi pangan fungsional yang bernilai gizi tinggi.

Kata Kunci: kacang lokal, pelatihan, pangan fungsional

Saat ini, kacang yang banyak dibudidayakan adalah kacang tanah, kacang hijau dan kedelai. Selain ketiga jenis kacang tersebut, terdapat juga jenis kacang-kacang lokal, diantaranya kacang kecipir, kacang tunggak, kacang jogo, kacang komak dan

komoditas unggulan yang berpotensi dikembangkan di wilayah Nusa Tenggara Barat. 
koro-koroan. Kacang komak (Lablab purpureus (L.) sweet) merupakan salah satu jenis kacang kacangan asli Indonesia yang banyak ditanam di daerah Jawa Timur dan NTB. Menurut Sudjarwo et.al., (2014), produktivitas kacang komak dapat mencapai 1.0-1.2 ton/ha, bahkan dapat mencapai 6 - 10 ton/hektar. Saat ini kacang komak banyak ditanam di daerah Jawa Timur dan Nusa Tenggara Barat (NTB), meskipun hanya sebagai tanaman tumpangsari. Penanaman belum dilakukan dalam skala luas, namun untuk tumpangsari, produksi kacang komak bisa mencapai 1,5 ton per hektar (Anonim, 2014).

Kandungan kacang komak dalam setiap $100 \mathrm{~g}$ adalah $9.6 \mathrm{~g}$ air, $25 \mathrm{~g}$ protein, $0.8 \mathrm{~g}$ lemak, $60.1 \mathrm{~g}$ karbohidrat, $1.4 \mathrm{~g}$ serat, $3.2 \mathrm{~g}$ abu, dan energi sebesar 335 kal. (Wulandari, 2018). Keistimewaan lainnya dari kacang komak adalah mengandung antioksidan 10 kali lipat dari asam askorbat, bersifat hipo-kolesterol (menurunkan kadar kolesterol) dan hipoglikemik (menurunkan kadar gula darah) (Wardani \& Pahriyani, 2018). Kadar protein kacang komak sebesar 21,5\%, susunan asam amino mendekati pola protein kedelai, yaitu kaya akan asam amino lisin, sedangkan asam amino metionin dan sistein kurang (Hartoyo, 2012; Cahyani dan Mardiatik, 2012). Kacang komak mempunyai kadar protein cukup tinggi dan komposisi asam amino yang baik sehingga berpotensi untuk mengatasi kekurangan protein. Kandungan serat pangan pada kacang komak mampu membantu mengontrol kadar lemak penyebab hiperkolesterolemia dan penyakitpenyakit kardiovaskular (Febrial, 2009). Berdasarkan potensi diatas, kacang komak sangat potensial untuk menggantikan kedelai dan dikembangkan menjadi pangan fungsional

Kacang kacangan lokal Indonesia seperti kacang kecipir, kacang tunggak, kacang jogo, kacang komak dan koro-koroan masih belum banyak dimanfaatkan. Kacang komak merupakan kacang-kacangan yang tergolong musiman dan pemanfaatannya masih belum maksimal. Umumnya kacang komak hanya di gunakan saat masih muda untuk disayur, direbus atau digoreng. Masyarakat menggunakan daun tanaman ini untuk hijauan pakan ternak, bahkan daun muda dapat dijadikan sayur (Suharjanto, 2010). Biji komak yang tua biasanya digunakan sebagai campuran makanan, sayur, sambal goreng atau emping. Dalam beberapa penelitian, biji kacang komak dibuat menjadi tahu
(Ratnaningtyas, 2003), tempe (Cahyani dan Mardiatik, 2012), kue brown, nugget (Cahyani dan Mardiatik, 2012), yoghurt (Wardani \& Pahriyani, 2018) dan food bar grits (Fath et.al., 2020).

Produksi kacang-kacangan di NTB pada tahun 2015 sebesar 156.205,47 ton, dimana produksi di Kabupaten Lombok Tengah kedua terbesar setelah Lombok Timur yaitu sebesar 30.695,57 ton (Badan Pusat Statistik Provinsi NTB, 2020). Namun saat ini, pengolahan kacangkacangan menjadi pangan fungsional sebagai sumber protein alternatif dan produk yang bernilai ekonomi tinggi masih sangat kurang. Permasalahan lainnya yang terjadi di masyarakat (mitra) adalah masih ditemukannya status stunting dan gizi buruk. Kasus stunting di Kabupaten Lombok Tengah mencapai 39,1\%, paling tinggi dibandingkan dengan kabupaten \& kota lainnya di Pulau Lombok (Anonim, 2018; Anonim, 2020). Salah satu penyebab terjadinya stunting dan gizi buruk adalah kurangnya pengetahuan masyarakat dan sosial ekonomi masyarakat. Selain itu, meningkatnya jumlah pengangguran pada kondisi pandemi saat ini juga menjadi masalah yang terjadi pada mitra. Berdasarkan potensi daerah dan permasalahan yang ada maka diperlukan edukasi ke masyarakat terkait diversifikasi pengolahan kacang-kacangan menjadi pangan fungsional sebagai sumber protein alternatif dan produk bernilai ekonomi sehingga dapat menjadi peluang usaha baru.

Ubung merupakan salah satu Desa yang terletak di wilayah Kecamatan Jonggat Lombok Tengah dengan jumlah penduduk sekitar 10.941 jiwa. Luas wilayah Desa Ubung 1.009,6 Ha yang terdiri dari 14 Dusun (Anonim, 2019). Wilayah Lombok Tengah merupakan salah satu sentra produksi kacang-kacangan dengan luas panen $31.601 \mathrm{Ha}$, sedangkan luas panen di Desa Ubung sekitar 205 Ha.

Pemanfaatan kacang-kacangan menjadi pangan fungsional ataupun produk yng bernilai ekonomi tinggi masih sangat terbatas. Khususnya kacang kacangan lokal seperti kacang kecipir, kacang tunggak, kacang jogo dan kacang komak juga masih belum banyak dimanfaatkan.

Permasalahan lainnya yang terjadi di masyarakat (mitra) adalah masih ditemukannya status stunting dan gizi buruk. Kasus stunting di Kabupaten Lombok Tengah mencapai 39,1\%, paling tinggi dibandingkan dengan kabupaten \& kota lainnya di Pulau Lombok (Anonim, 2018; 
Anonim, 2020). Salah satu penyebab terjadinya stunting dan gizi buruk adalah kurangnya pengetahuan masyarakat dan sosial ekonomi masyarakat. Berdasarkan data statistik Kecamatan Jonggat, di Ubung terdapat sekitar 35,47\% kepala keluarga yang tidak bekerja dan $\pm 13,60 \%$ yang bekerja lepas. Selain itu, meningkatnya jumlah pengangguran pada kondisi pandemi saat ini juga menjadi masalah yang terjadi pada mitra. Berdasarkan potensi daerah dan permasalahan yang ada maka diperlukan edukasi ke masyarakat terkait diversifikasi pengolahan kacang lokal Lombok menjadi pangan fungsional sebagai sumber protein alternatif dan produk bernilai ekonomi sehingga dapat menjadi peluang usaha baru.

\section{Metode}

Tahapan-tahapan yang akan dilakukan dalam melaksanakan solusi yang ditawarkan pada mitra adalah:

1. Tahap persiapan: koordinasi dengan mitra terkait dengan jumlah remaja yang tergabung dalam karang taruna Desa Ubung yang menjadi peserta kegiatan pengabdian. Selain itu dilakukan proses perijinan dan melakukan kontrak waktu dengan koordinator mitra. Tim pengabdian menyiapkan materi pelatihan, alat dan bahan yang diperlukan untuk kegiatan pelatihan

2. Tahap Pelaksanaan: (1) Penyuluhan dan diskusi. Pada sesi ini dilakukan juga pengukuran pengetahuan dan pemahaman peserta terkait topik penyuluhan yang diberikan. Metode yang digunakan adalah tim pengabdian memberikan pertanyaan kepada peserta secara langsung tentang pangan fungsional dan pengolahan kacang lokal menjadi produk bergizi tinggi. Selanjutnya tahap penyampaian materi tentang nilai gizi dan nutrisi kacangkacangan, pengolahan kacang lokal Lombok menjadi pangan fungsional sebagai sumber protein alternatif dan produk bernilai ekonomi sehingga hal ini menjadi peluang usaha bagi mitra. Selain itu akan disampaikan juga materi tentang pengemasan produk pangan. Diskusi bertujuan untuk memberikan kesempatan bagi mitra yang ingin bertanya secara lebih mendalam tentang materi yang disampaikan. (2) Demontrasi/praktek bertujuan untuk memberikan gambaran secara langsung tentang materi yang disampaikan dan bertujuan agar mitra dapat mempraktekkan materi yang telah diterima.

3. Tahap evaluasi, bertujuan untuk mengetahui sejauh mana peningkatan pengetahuan mitra terhadap materi yang telah disampaikan

\section{Hasil dan Pembahasan}

Tahap persiapan dimulai dengan koordinasi jadwal antara tim pengabdian, perangkat Desa Ubung, dan peserta pelatihan. Selain itu, tim melakukan pembuatan leaflet pelatihan, pengadaan alat dan bahan yang akan digunakan untuk kegiatan praktek. Tim pengabdian melaksanakan kegiatan dalam bentuk penyuluhan dan praktek sesuai dengan jadwal yang telah ditentukan.

Tahap pelaksaaan kegiatan pengabdian dilaksanakan dalam bentuk penyuluhan dan praktek pembuatan produk pangan fungsional berbasis kacang lokal. Kegiatan dilakukan di aula Kantor Desa Ubung. Kegiatan terdiri dari 2 sesi yaitu sesi penyampaian materi tentang jenis kacang lokal Lombok, kandungan nutrisi, pangan fungsional berbasis kacang lokal, pengemasan produk dan sesi praktek membuat produk pangan fungsional yaitu tempe komak, nugget tempe komak dan sari kacang merah.

Pada sesi pertama, dilakukan pembukaan oleh tim pengabdian, penyampaian teknis pelaksanaan kepada peserta dan pemaparan materi dilakukan oleh tim pengabdian (Gambar 1). Adapun materi yang disampaikan meliputi jenis kacang lokal yang terdapat di Pulau Lombok, kandungan nutrisi pada kacang-kacangan, pangan fungsional, pengolahan kacang lokal menjadi produk pangan bergizi tinggi dan pengemasan produk. Pada sesi pertama dilakukan juga pengukuran 
pengetahuan dan pemahaman peserta terkait topik penyuluhan yang diberikan. Metode yang digunakan adalah tim pengabdian memberikan pertanyaan kepada peserta secara langsung tentang apa yang dimaksud dengan pangan fungsional dan pengolahan kacang lokal menjadi produk bergizi tinggi. Informasi yang diperoleh dari sesi ini adalah semua peserta pengabdian sebanyak 16 orang belum mengetahui tentang pangan fungsional dan belum mengetahui bahwa kacang komak dapat digunakan untuk mengganti kacang kedelai dalam membuat produk tempe, begitu juga dengan pembuatan nugget dan sari kacang merah. Umumnya kacang-kacangan di wilayah Ubung diolah menjadi sambal, lauk atau sayur.

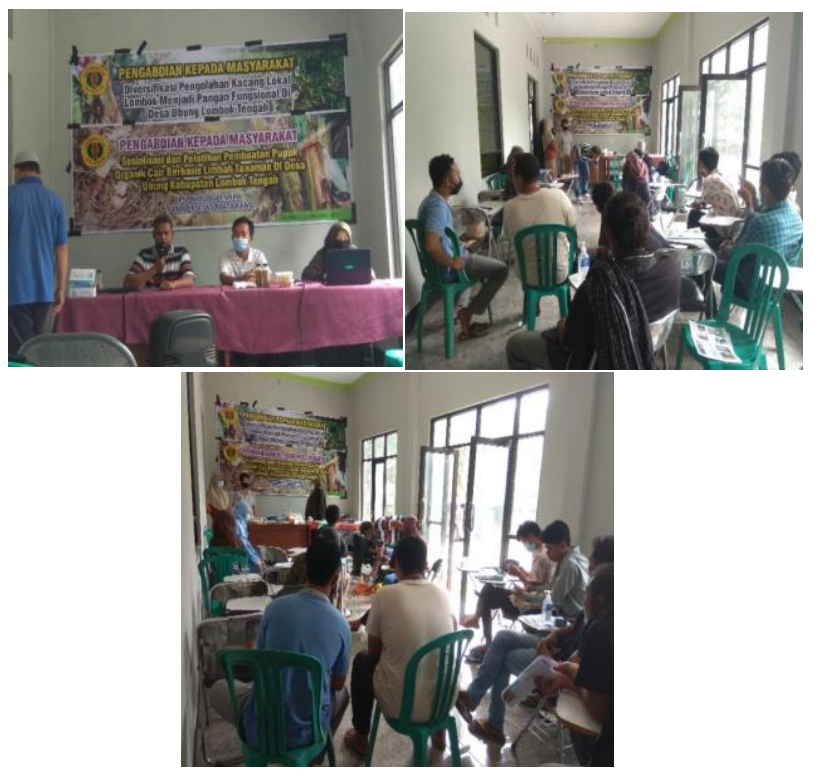

Gambar 1. Kegiatan pengabdian: sesi penyampaian materi oleh tim pengabdian

Sesi kedua adalah kegiatan praktek (Gambar 2). Kegiatan ini dilengkapi dengan leaflet tahapan pembuatan produk yang diberikan kepada setiap peserta. Kegiatan praktek meliputi, pembuatan tempe komak, nugget tempe komak dan sari kacang merah. Pada sesi praktek, peserta juga diminta untuk melakukan uji organoleptik dari tempe komak, nugget dan sari kacang merah.

Antusiasme peserta pada kegiatan praktek sangat tinggi, ini dilihat dari keaktifan peserta dan pertanyaan yang diajukan kepada tim pengabdian. Beberapa pertanyaan yang diajukan oleh peserta diantaranya terkait dengan masa simpan tempe komak, kualitas tempe komak (aroma, rasa) dan peluang usaha untuk mengembangkan tempe komak. Setelah kegiatan praktek maka dilakukan kegiatan evaluasi untuk mengetahui tingkat pemahaman dan pengetahuan peserta setelah pelatihan. Berdasarkan hasil evaluasi, terjadi peningkatan pengetahuan dan pemahaman peserta tentang pengolahan kacang lokal menjadi pangan fungsional yang bernilai gizi tinggi.

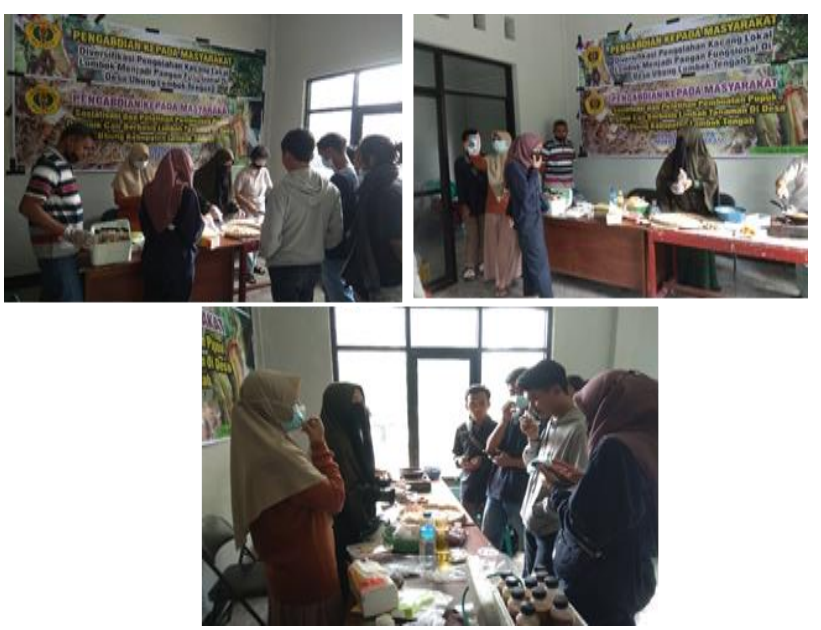

Gambar 2. Kegiatan pengabdian: sesi praktek pembuatan produk pangan fungsional berbasis kacang lokal

\section{Kesimpulan}

Kegiatan pengabdian diversifikasi pengolahan kacang lokal Lombok menjadi pangan fungsional dapat membantu meningkatkan pengetahuan dan keterampilan mitra pengabdian. Hal ini dapat dilihat dari antusiasme peserta selama kegiatan pengabdian dan meningkatnya pengetahuan peserta tentang topik yang disuluhkan.

Saran Kegiatan pendampingan yang intensif kepada mitra perlu dilakukan dan memberikan pengetahuan tentang peluang usaha serta analisis ekonomi produk pangan berbasis kacang lokal. 


\section{Ucapan Terima Kasih}

Penulis mengucapkan terima kasih kepada Universitas Mataram yang telah memberi dukungan financial terhadap kegiatan pengabdian ini.

\section{Daftar Pustaka}

Anonim, 2014. Komak Digadang-gadang Menjadi Pengganti Kedelai. https://www.jitunews.com/read/7205/ko mak-digadang-gadang-jadi-penggantiimpor-kedelai. Tanggal akses: 13 Februari 2021.

Anonim, 2018. Data Kesehatan Lombok Tengah. https://lomboktengahkab.go.id/. Tanggal akses: 13 februari 2021.

Anonim, 2019. Statistik dan Spasial Kecamatan Jonggat 2019. BPS Kabupaten Lombok Tengah. Lombok Tengah.

Anonim, 2020. Posyandu Keluarga Pusat Edukasi dan Solusi Masalah Sosial. https://dp3ap2kb.ntbprov.go.id/2020/10/1 9/posyandu-keluarga-pusat-edukasi-dansolusi-masalah-sosial/. Tanggal akses: 13 Februari 2021.

Badan Pusat Statistik Provinsi NTB, 2020. Luas Panen, Produksi, dan Produktivitas Kacang Hijau, Kacang Tanah, Kedelai 2013-2015. https://ntb.bps.go.id/. Tanggal akses: 13 Februari 2021.

Cahyani, A dan Mardiatik, S., 2012. Lab Lab Nugget Makanan Sumber Protein Nabati Bermutu dan Bergizi Tinggi. Jurnal Riset Daerah. 11(2): 1750-1766.

Fath, H.K., Hanifah, I., Putri, W.D.R., 2020. Formulasi Food Bar Grits Kacang Komak dan Kacang Kedelai Hitam Menggunakan Metode Linear Programming. Jurnal Teknologi Hasil Pertanian. 8(1): 29-45.

Haryoto, 1996. Susu dan Yogurt Kecipir. Penerbit Kanisisun. Yogyakarta.

Hartoyo, A 2012. Potensi Protein Kacang Komak Sebagai Bahan Pangan
Fungsional Hipoglikemik. Food Review Indonesia. 7(4): 49-53.

Ratnaningtyas, A., 2003. Tahu dari Kacang Non Kedelai; Studi Kasus Kacang Komak. Skripsi. Institut Pertanian Bogor. Bogor.

Suharjanto, T., 2010. Respon hasil kacang komak terhadap intensitas cekaman kekeringan. Jurnal Agrika. 4(1): 30-36.

Wardani, E dan Pahriyani, A., 2018. Aktivitas Yoghurt Kacang Komak (Lablab purpureus (L.) Sweet) Sebagai Antihiperglikemia. Jurnal Jamu Indonesia. 3(1): 18-25.

Wulandari, R., 2018. Kualitas Kefir Kacang Komak Perisa Buah Naga dengan Waktu Inkubasi dan Konsentrasi Starter Berbeda. Skripsi. PS Pendidikan Biologi FKIP UMS. Surakarta. 